Удк 616-007.43-089:796.332-051

DOI 10.11603/2414-4533.2020.4.11777

๑О. Ю. ІОФФЕ, А. В. ОМЕЛЬЧЕНКО, О. П. СТЕЦЕНКО, Т. В. ТАРАСЮК

Національний медичний університет імені О. О. Богомольця

\title{
Особливості хірургічного лікування спортивної грижі у футболістів
}

\begin{abstract}
Мета роботи: визначити оптимальну тактику вибору хірургічного лікування спортивної грижі у футболістів.
Матеріали і методи. Проведено аналіз результатів хірургічного лікування 36 футболістів професійних та аматорських клубів віком від 18 до 34 років із діагнозом спортивна грижа, які перебували в хірургічному відділенні КМКЛ № 3 впродовж 2014-2019 pр.

Хворих було розподілено на дві групи дослідження залежно від методики хірургічного втручання. В першій групі виділено дві підгрупи, до першої підгрупи хворих увійшли 10 футболістів, яким виконували лапароскопічну інтраперитонеальну герніоалопластику за методикою IPOМ. До другої підгрупи увійшли 8 футболістів, яким виконували лапароскопічну інтраперитонеальну герніоалопластику за методикою IPOM із субдермальним ушиванням внутрішніх пахових кілець. До другої групи увійшли 18 футболістів, яким виконували лапароскопічну трансабдомінальну преперитонеальну герніоалопластику за методикою ТАРР. Для оцінки показників якості життя застосовували опитувальник The Copenhagen Hip and Groin Outcome Score (HAGOS) та Eura HS Quality of Life score (Eura HS-QoL у модифікації).

Результати досліджень та їх обговорення. При аналізі показників за шкалою HAGOS якість життя до операції не відрізнялась в обох групах дослідження, тоді як після проведення хірургічного лікування значно підвищилась у другій групі з 47 до 96 балів та в першій групі з 45 до 80 балів (р<0,05). Також в другій групі встановлено достовірне зменшення больового синдрому в пахвинній ділянці після лапароскопічної герніоалопластики за методикою ТАРР з 8 балів до 2 балів за шкалою ВАШ і після застосування методики IPOM у першій групі з 7,5 до 3 балів (р<0,05). Найкоротший термін повернення спортсмена до тренувань становить 3 тижні після хірургічного лікування спортивної грижі виявлено при лапароскопічній пластиці задньої стінки пахового каналу за методикою ТАРР зі встановленням самофіксуючої сітки.

У дослідженні проведено порівняльний аналіз результатів лапароскопічних хірургічних втручань та визначено оптимальну тактику вибору хірургічного лікування спортивної грижі у футболістів.
\end{abstract}

Ключові слова: спортивна грижа; хірургічне лікування; футболісти; ТАРР; IPOM; біль у пахвинній ділянці.

Постановка проблеми і аналіз останніх досліджень та публікацій. Термін “спортивна грижа” характеризується наявністю стійкого болю у спортсмена в пахвинній ділянці при виконанні специфічних фізичних навантажень, основною причиною якої $є$ ділянка “слабкості” задньої стінки пахвинного каналу та різні варіанти структурно-анатомічних змін пахвинного каналу без типових ознак грижі передньої черевної стінки [1-4]. Біль у пахвинній ділянці складає 0,5-6,2 \% від усіх звернень спортсменів до лікаря [5].

Для більшості спортсменів є складним викликом зупинити тренування, що є необхідною умовою консервативного лікування больового синдрому в пахвинній ділянці, саме тому пріоритетом у виборі $\epsilon$ xiрургічне лікування. За результатами досліджень деяких спеціалізованих центрів пацієнти оцінюють результати хірургічних втручань від 70 до 90 \% як “добрі” та “відмінні” [5-10].

На сьогодні у світі для лікування спортивної грижі застосовують лапароскопічні та відкриті методики хірургічних втручань [24]. Хірургічні втручання відкритими методиками застосовуються у пацієнтів зі спортивною грижею із або без використання сітчастого алотрансплантату. Серед лапароскопічних методик, які мають низку пере- ваг над відкритими, для хірургічного лікування спортивної грижі застосовують лапароскопічну трансабдомінальну передочеревинну герніоалопластику (ТАРР). В дослідженні Васильєва А. В. [11] представлені переваги застосування лапароскопічної інтраперитонеальної герніоалопластики (IPOM) як операції вибору при лікуванні гриж пахвинної ділянки.

Невирішеним залишається проблема вирішення щодо хірургічного втручання спортсмену на неураженій стороні, якщо симптоми болю є однобічними. Немає єдиного погляду щодо показань до хірургічного втручання в пацієнтів зі спортивною грижею. [8] Також дискутабельним залишається питання способів фіксації сітчастих алотрансплантатів, а поліморфізм анатомічних змін при спортивній грижі спонукає до пошуку нових підходів хірургічного лікування цієї патології у футболістів, що буде сприяти скороченню термінів їхньої професійної реабілітації.

Мета роботи: визначити оптимальну тактику вибору хірургічного лікування спортивної грижі у футболістів.

Матеріали і методи. Проведено аналіз результатів хірургічного лікування 36 футболістів 
професійних та аматорських клубів віком від 18 до 34 років з діагнозом спортивна грижа, які перебували на лікуванні в хірургічному відділенні КМКЛ № 3 впродовж 2014-2019 рр.

Усі спортсмени отримували курс консервативного лікування в умовах спортивних клубів із приводу болю в пахвинній ділянці, лонного симфізу та привідних м'язів стегна (ARS-синдрому з англ. adductor-rectus-symphisis syndrome), але відсутність ефекту та неможливість продовжувати професійну діяльність було причиною для звернення.

Хворих було розподілено на дві групи залежно від методики хірургічного втручання. В першій групі виділено дві підгрупи, до першої підгрупи хворих увійшли 10 футболістів, яким виконували лапароскопічну інтраперитонеальну герніоалопластику за методикою IPOM. До другої підгрупи увійшли 8 футболістів, яким виконували лапароскопічну інтраперитонеальну герніоалопластику за методикою IPOM з двобічним субдермальним ушиванням внутрішніх пахових кілець. До другої групи увійшли 18 футболістів, яким виконували лапароскопічну трансабдомінальну преперитонеальну герніоалопластику за методикою ТАРР.

Для оцінки показників якості життя застосовували опитувальник The Copenhagen Hip and Groin Outcome Score (HAGOS), що є специфічним для спортсменів із патологією пахвинної ділянки та стегна, він складається з 6 окремих пунктів: “біль” (10 підпунктів); “симптоми” (7 підпунктів); “щоденна рухова активність” (5 підпунктів); “фізична активність у спорті” (8 підпунктів); “участь у спортивних змаганнях" (2 підпункта) та “якість життя” (5 підпунктів), кожний підпункт оцінюється від 0 до 4 балів, де 0 - відповідає відсутності скарг, 4 - найбільш вираженим скаргам. Далі бали підраховуються в шкалу від 0 до 100 балів, де 0 значний біль в ділянці пахвини та стегна, 100 відсутність болю в пахвинній ділянці та ділянці стегна [12].

Для оцінки показників болю, обмеження рухової активності та наявності косметичного дефекту в доопераційному та післяопераційному періоді застосовували опитувальник Eura HS Quality of Life score (Eura HS-QoL в модифікації). За шкалою ВАШ проводили оцінку від 0 до 10, де 0 для задовільного стану, а 10 - для найбільш незадовільного стану (виражений біль, повне обмеження активності, косметичний дефект) [13].

Для представлення даних, які не підпорядковуються нормальному закону розподілу, визначали медіану (Ме), перший та третій квартилі $\left(\mathrm{Q}_{\mathrm{I}}-\mathrm{Q}_{\mathrm{III}}\right)$, у випадку нормального закону розподілу визначали середнє значення (М) та стандартне відхилення $( \pm \mathrm{SD})$. При порівнянні кількісних показників у двох групах використано критерій Ст’юдента для нормального закону розподілу даних, або U-критерій Манна-Уїтні для закону розподілу відмінного від нормального. Для виявлення відмінностей після проведеного хірургічного лікування використано критерій Ст'юдента для пов'язаних вибірок для нормального закону розподілу даних та Т-критерій Вілкоксона для закону розподілу відмінного від нормального. Порівняння ефективності методів операційного втручання проводили за показником відношенння ризиків (ВР), наведено його 95 \% вірогідний інтервал (95% ВI). Критичний рівень значимості прийнято рівним 0,05.

Аналіз результатів проведений в статистичномy пакеті EZR v.1.50 (R statistical software version 4.0, R Foundation for Statistical Computing, Vienna, Austria) [16].

Результати досліджень та їх обговорення. В обох групах дослідження проведено аналіз показників до та після хірургічного втручання за результатами опитувальників HAGOS та Eura HS-QoL в модифікації. Критерієм ефективності хірургічного лікування спортивної грижі визначено відсутність болю під час удару по м’ячу, що визначало терміни повернення спортсмена до тренувань та показник якості життя. Професійним футболістам також проведено оцінку кар'єрних досягнень.

У таблиці 1 представлено результати анкетування футболістів до та після хірургічного лікування.

У футболістів обох груп показник інтенсивності болю та показник обмеження рухової активності під час занять спортом до операції не відрізнявся, біль за шкалою ВАШ у першій групі - 7,5 $(6,25-10)$ балів, у другій групі - $8(6,25-10)$ балів $(\mathrm{p}=0,89)$ та обмеження рухової активності - 7 (6$8)$ та $8(6,25-8)$ балів $(p=0,53)$ відповідно.

У другій групі після застосування методики ТАРР відбулося достовірне зменшення больового синдрому в пахвинній ділянці з 8 балів до 2 балів за шкалою ВАШ, після застосування методики IPOM в першій групі - з 7,5 до 3 балів $(\mathrm{p}<0,05)$.

При аналізі показників за шкалою HAGOS якість життя до операції не відрізнялась в обох групах дослідження, тоді як після проведення хірургічного лікування значно підвищилась у другій групі з 47 до 96 балів та в першій групі з 45 до 80 балів $(\mathrm{p}<0,05)$.

Враховуючи показники відношення ризиків у двох групах виявлено, що при виконанні хірургічного втручання за методикою ТАРР ризик випадку негативного результату знижується.

У таблиці 2 представлено результати операції за методикою ТАРP та IPOM у 36 футболістів. 
Таблиця 1. Результати хірургічного лікування 36 фрутболістів

\begin{tabular}{||l|c|c|c||}
\hline \multicolumn{1}{|c|}{ Методика хірургічного втручання } & $\begin{array}{c}\text { TAPP } \\
(\mathrm{n}=18)\end{array}$ & IPOM (n=18) & $\begin{array}{c}\text { Рівень значущості відмінності } \\
\text { між групами, p }\end{array}$ \\
\hline Біль за ВАШ до операції (бали) & $8(6,25-10)$ & $7,5(6,25-10)$ & 0,89 \\
\hline Біль за ВАШ після операції (бали) & $2 *(2-3)$ & $3 *(3-4)$ & $0,006^{*}$ \\
\hline $\begin{array}{l}\text { Обмеження рухової активності до операції } \\
\text { (бали) }\end{array}$ & $8(6,25-8)$ & $7(6-8)$ & 0,73 \\
\hline $\begin{array}{l}\text { Обмеження рухової активності після } \\
\text { операції (бали) }\end{array}$ & $0(0-1,0)$ & $0(0-0,73)$ & 0,49 \\
\hline Якість життя до операції за НАGOS (\%) & $47(40-55)$ & $45(36-53)$ & $0,001^{*}$ \\
\hline Якість життя після операції за HAGOS (\%) & $95 *(95-100)$ & $80 *(76,25-85)$ & 0,53 \\
\hline \hline
\end{tabular}

Примітки: *-відмінність показників після лікування (у відповідній групі) статистично значуще відрізняється від показників до лікування, $<<0,05$.

Таблиця 2. Результати операції за методикою ТАРP та IPOM

\begin{tabular}{||l|c|c|c||}
\hline \multicolumn{1}{|c|}{ Методика хірургічного втручання } & $\begin{array}{c}\text { ТАРР } \\
(\mathrm{n}=18)\end{array}$ & $\begin{array}{c}\text { ІРОМ } \\
(\mathrm{n}=18)\end{array}$ & $\begin{array}{c}\text { Рівень значущості } \\
\text { відмінності між } \\
\text { групами, p }\end{array}$ \\
\hline Час операції (хвилини) & $62,0(60-64)$ & $58,5(44,25-79,5)$ & 0,98 \\
\hline Тривалість перебування у стаціонарі & $1,05 \pm 0,41$ & $1,16 \pm 0,51$ & 0,65 \\
\hline Відсутність болю під час удару по м’ячу (дні) & $22(21-23)$ & $27(25-28)$ & $0,001 *$ \\
\hline Результат операції через 1 міс. (+/-) & $15 / 3$ & $6 / 12$ & 0.005 \\
\hline $\begin{array}{l}\text { Результат лікування через 1 рік } \\
\text { “відмінно”/“добре”/“задовільно” }\end{array}$ & $\begin{array}{c}\text { “відмінно”-10 } \\
\text { “добре”-8 }\end{array}$ & $\begin{array}{c}\text { “відмінно”-10 } \\
\text { “добре”-8 }\end{array}$ \\
\hline \hline
\end{tabular}

Важливим чинником $є$ усунення післяопераційного больового синдрому. В першій групі пацієнтам призначали знеболювальні препарати “за вимогою” впродовж 5 діб, в другій групі - 3 діб. Виявлено різницю в інтервалі введення знеболювальних впродовж перебування в стаціонарі в першу п/о добу: в 1 групі пацієнти в ранньому післяопераційному періоді вказували появу болю через 12 год після останнього введеного знеболювального, а в 2 групі - через 19 год.

У першій групі в 10 пацієнтів у першій підгрупі, яким герніопластику виконували за методикою IPOM та у 8 пацієнтів другої підгрупи після герніопластики за методикою IPOМ з ушиванням внутрішніх пахових кілець, середня тривалість перебування в стаціонарі становила $(1 \pm 0)$ діб та $(1,37 \pm 0,74)$ відповідно. У другій групі у 18 пацієнтів, які перенесли герніопластику за методикою ТАРP, середня тривалість перебування в хірургічному стаціонарі становила $(1,05 \pm 0,41)$ доби.
Час операції за методикою ТАРР становить 61,27 (60-64) хв, за методикою IPOM - 46 (42,545) хв, за методикою IPOM з ушиванням внутрішніх пахових кілець - 79,62 $(77,25-82,75)$ хв $(\mathrm{p}<0,05)$.

У дослідженні ми визначили критерії відбору спортсменів для проведення хірургічного втручання.

Критерії до хірургічного лікування:

1. Наявність пролабування задньої стінки пахового каналу.

2. Підвищення МР-сигналу від структур пахових каналів (рис. 1).

3. Підвищення МР-сигналу від гілок лонної кістки.

4. Різниця розмірів між паховими проміжками на УЗД пахвинних ділянок.

5. Розширення пахового проміжку більше 11 мм.

6. Розширення внутрішнього пахового кільця більше 10 мм. 


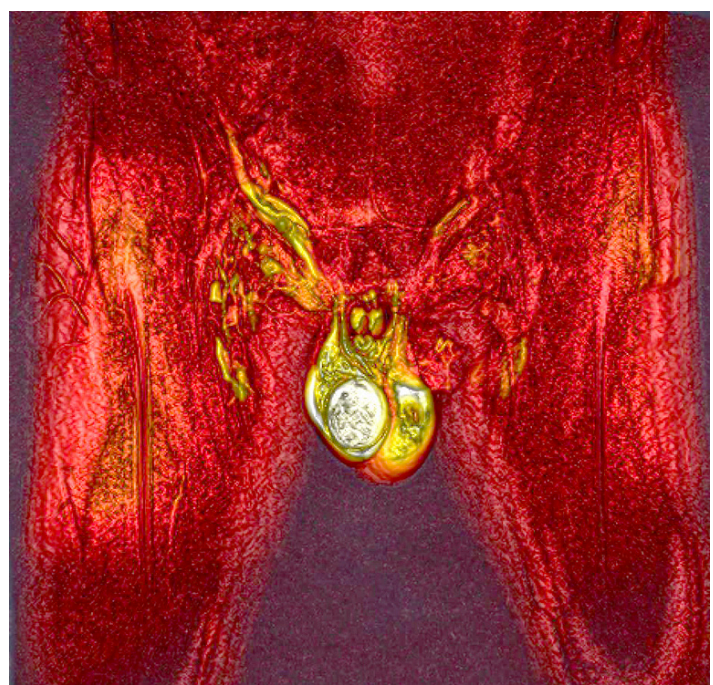

Рис. 1. Підвищення МР-сигналу від структур пахвинних каналів.

7. Відсутність позитивного ефекту від консервативного лікування більше 6 тижнів.

8. Біль у пахвинній ділянці має одно/двобічний характер.

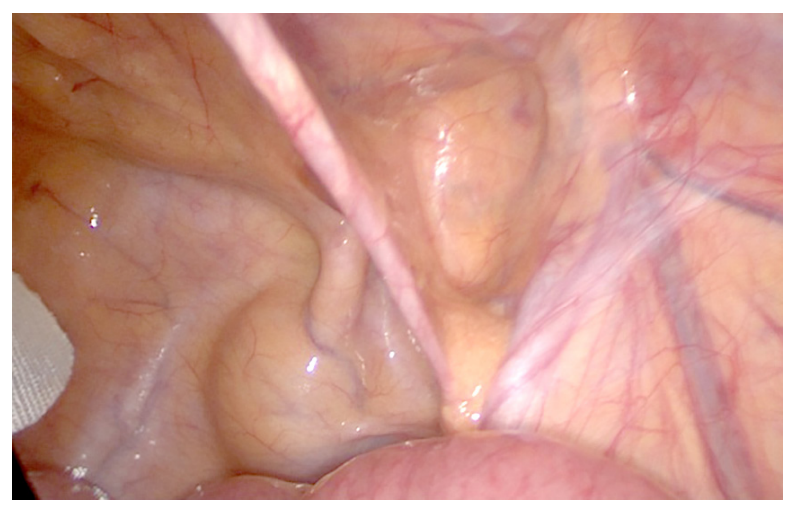

a

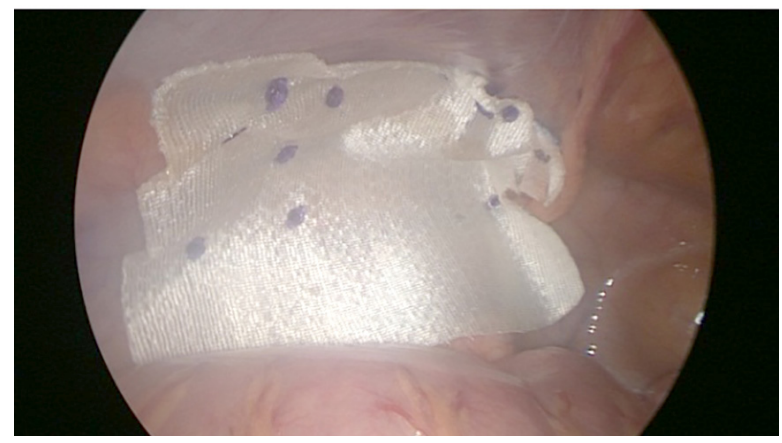

B
9. Больовий синдром впродовж 4-6 тижнів.

10. Результати анкетування HAGOS (обмеження фізичної активності спортсмена та його участі в спортивних змаганнях, зниження якості життя).

11. Зміщення латерального краю прямого м’яза живота на МРТ пахвинної ділянки.

У першій підгрупі 10 футболістам виконували лапароскопічну інтраперитонеальну герніоалопластику за методикою IPOМ. Основною метою цієї методики було укріплення задньої стінки пахвинного каналу зі встановленням сітчастого трансплантату без розкриття очеревини з фіксацією його скобками, що розсмоктуються. Поставлену задачу досягали через встановлення порту 10 мм над пупком та двох троакарів 5 та 12 мм у лівій та правій здухвинних ділянках. Так досягали візуалізації анатомічних структур обох пахвинних ділянок та визначення горбка лонної кістки методом інструментальної пальпації з 9 до 15 год умовного циферблату. Потім у проекції латеральної та медіальної пахових ямок пахової ділянки проводили фіксацію синтетичної композитної сітки з антиспайковим покриттям без розсічення очеревини, яку виконували за допомогою герніостеплера з фіксаторами із матеріалу, що розсмоктуються (рис. 2).

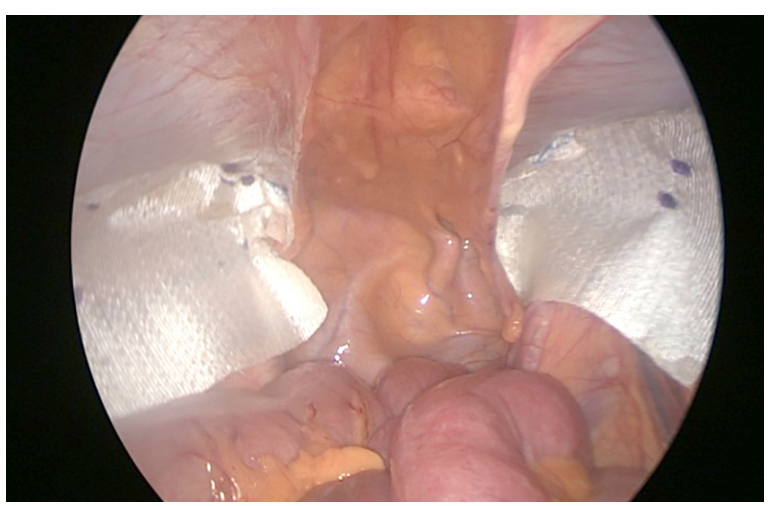

б

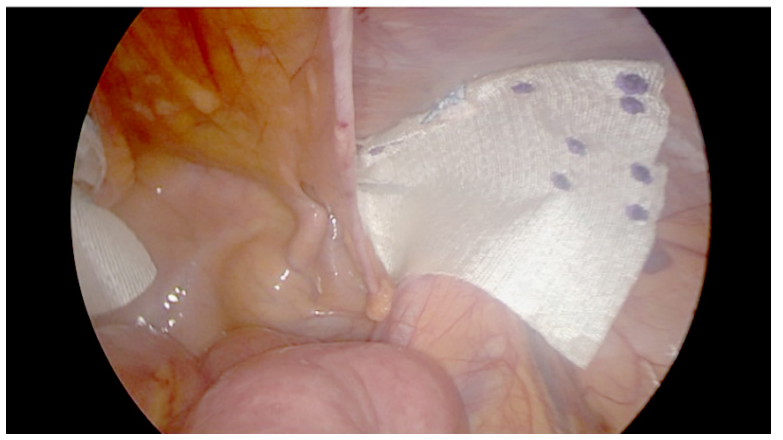

$\Gamma$

Рис. 2. Етапи операції за методикою ІРОМ при спортивній грижі у футболіста: а - візуалізація проекції медіальної та латеральної пахових ямок; б - двобічна герніопластика спортивної грижі з фіксацією сітчастого трансплантату до задньої стінки пахвинного каналу за методикою IPOM; в і г - фіксація сітчастого трансплантату за методикою IPOМ зліва та справа (г) за допомогою герніостеплера зі скобами, що розсмоктуються. 
Завдяки чому втручання було малотравматичним та у післяопераційному періоді пацієнти вказували на меншу необхідність у знеболенні, також скоротився час проведення операції та терміни реабілітації спортсмена. При інтраопераційній ревізії при IPOМ виявлено такі ознаки спортивної грижі: пролабування задньої стінки пахвинного каналу. Визначено показання до лапароскопічної інтраперитонеальної герніоалопластики за методикою IPOM: 1) неефективність консервативної терапії; 2) необхідність продовжувати заняття спортом; 3) різниця розмірів пахових каналів від 0,2 до 2 мм; 4) підвищення МР- сигналу від пахового каналу визначається справа або з обох сторін; 5) біль $є$ однобічним/двобічним за ВАШ від 5 до 9 балів.

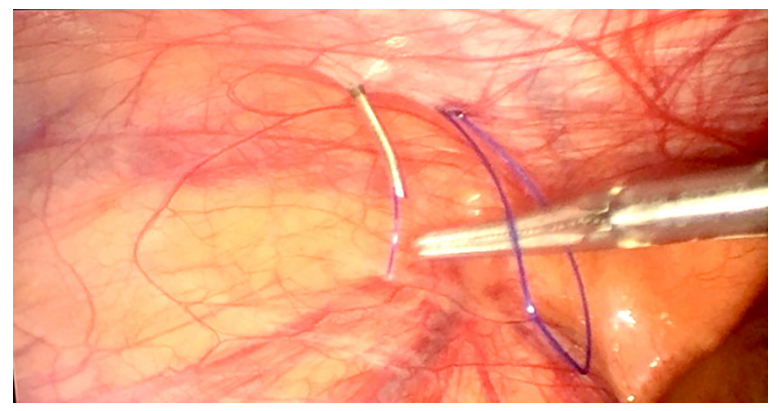

a
У другій підгрупі 8 футболістам виконували лапароскопічну інтраперитонеальну герніоалопластику за методикою IPOM із субдермальним ушиванням внутрішніх пахових кілець. Даний спосіб відрізнявся від лапароскопічної інтраперитонеальної герніоалопластики за методикою IPOМ тим, що при виявленні розширеного внутрішнього пахового кільця виконували його субдермальне ушивання за допомогою поліпропіленової нитки 2-0. При інтраопераційній ревізії пахвинних ділянок виявлено такі ознаки спортивної грижі: пролабування задньої стінки пахвинного каналу, розширення внутрішніх пахових кілець (рис. 3).

Визначено показання до ушивання внутрішнього пахового кільця: 1) розміри внутрішнього пахового кільця > 10 мм.

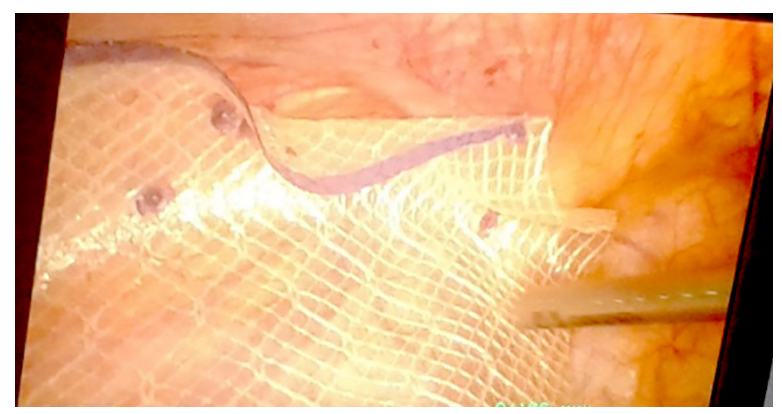

б

Рис. 3. Етапи операції IPOМ з ушиванням внутрішнього пахового кільця при спортивній грижі у футболіста: а - етапи субдермального ушивання внутрішнього пахового кільця за допомогою поліпропіленової нитки; б - фіксація композитного сітчастого алотрансплантату за допомогою герніостеплера зі скобами, що розсмоктуються.

У другій групі 18 футболістам виконували лапароскопічну трансабдомінальну преперитонеальну герніоалопластику за методикою ТАРР із застосуванням самофіксуючої сітки без додаткової фіксації скобами герніостеплера. Спосіб лапароскопічної герніоалопластики за методикою ТАРР виконували наступним чином: під загальним знеболенням проводили розріз шкіри до 1 см над пупком, в черевну порожнину вводили голку Вереша для інсуфляції вуглецю. Після формування карбоксиперитонеуму з внутрішньочеревним тиском до 12 мм рт. ст. через даний доступ вводили 10 мм троакар для відеокамери. Після введення оптики проводили ревізію черевної порожнини, огляд обох пахвинних ділянок (рис. 4, а). Далі в лівій здухвинній ділянці на стороні дефекту вводили 5 мм троакар. На тому ж рівні з протилежного боку вводили 12 мм троакар (перевага 12 мм троакару зумовлена необхідністю безпечного та легкого введення сітчастого імплантату в черевну порожнину). Виконували дугоподібний розріз парієтального листка очеревини в медіальному та латеральному напрямках над верхнім краєм дефекту поперечної фасції (рис. 4, б). Клапоть очеревини тупим та гострим шляхом атравматично відділяли від прилеглих анатомічних структур та поперечної фасції, огинаючи латеральну та медіальну пахові ямки. Після цього виконували підготовку (розмітка та орієнтація) сітчастого самофіксуючого алотрансплантату та введення його в черевну порожнину (рис. 4, в, е). Заключним етапом хірургічного втручання $є$ відновлення парієтальної очеревини для повної ізоляції алотрансплантату від вільної черевної порожнини, що виконують за допомогою безвузлового ушивання ниткою, що розсмоктується V-Loc (рис. 4, є).

При інтраопераційній ревізії за методикою ТАРР виявлено такі ознаки спортивної грижі: пролабування задньої стінки пахвинного каналу, розширення внутрішнього пахового кільця (рис. 4, г), наявність спайкового процесу (рис. 4, д), наявність грижі, що формується. Визначено показання до лапароскопічної герніоалопластики за методикою 


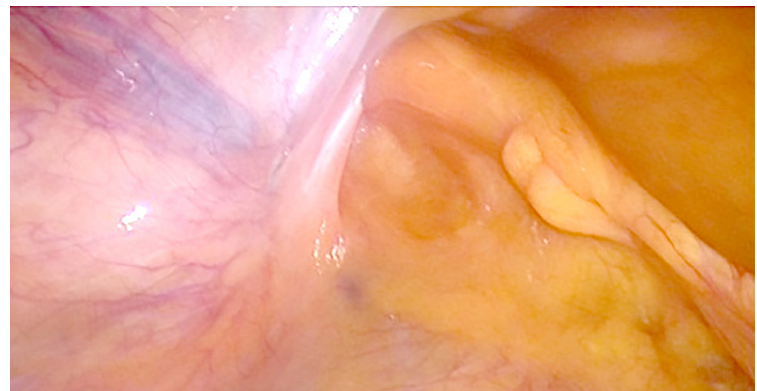

a

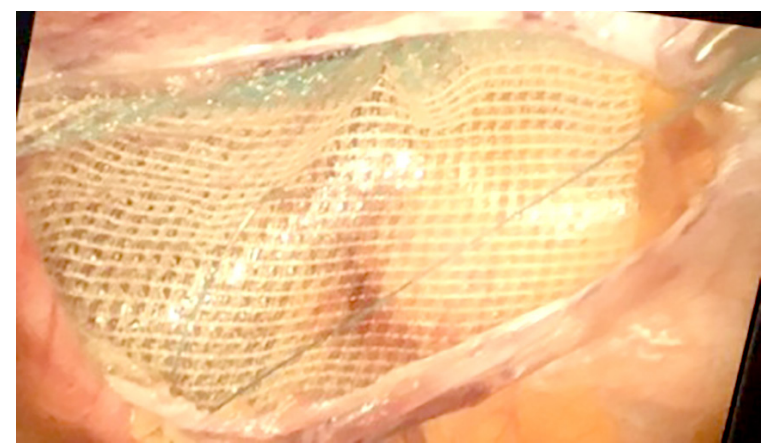

B

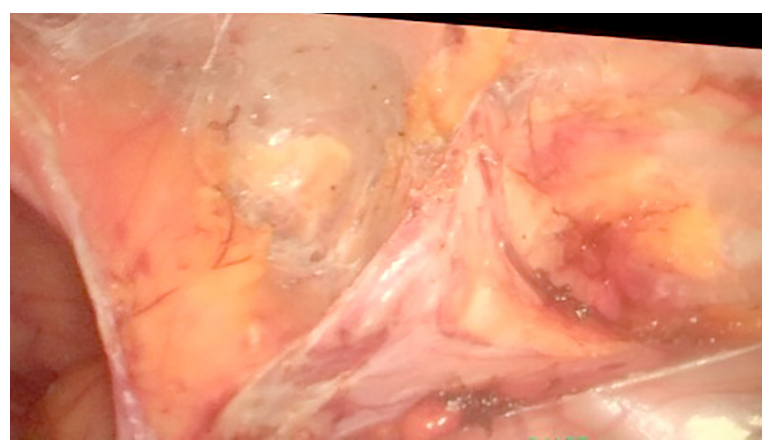

Д

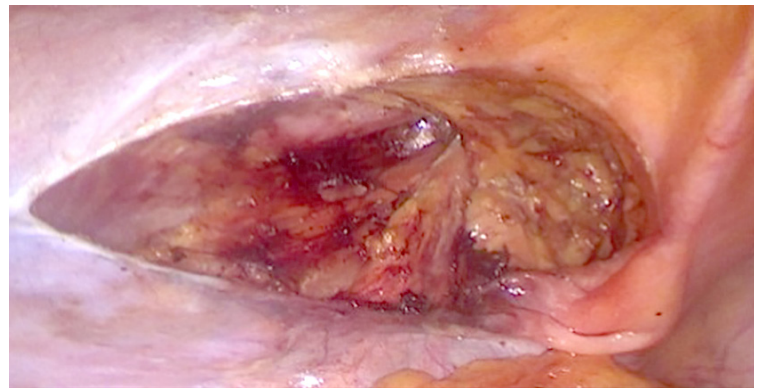

б

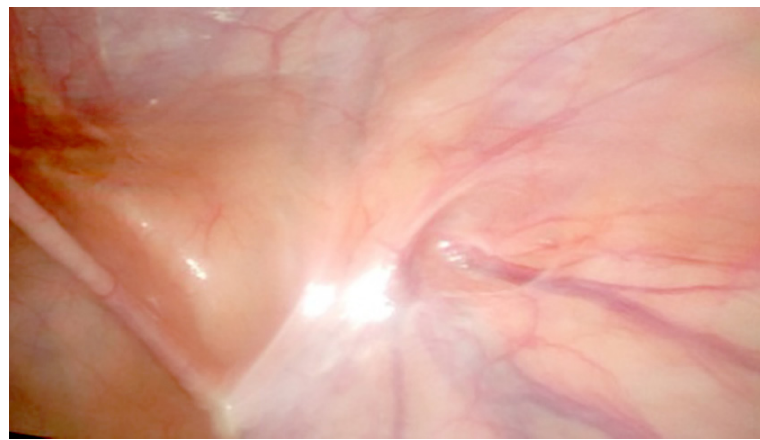

$\Gamma$

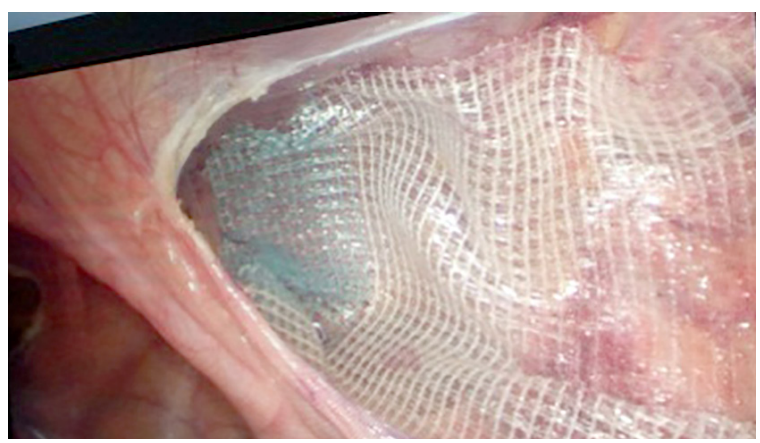

e

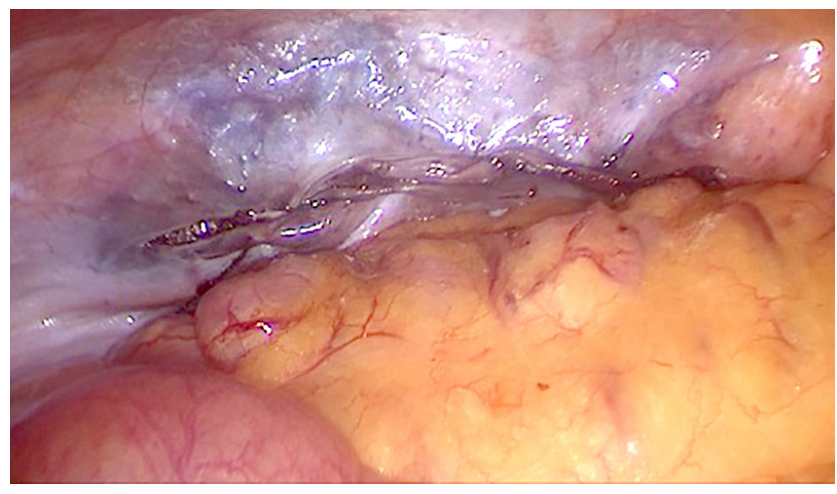

$\epsilon$

Рис. 4. Етапи операції ТАРР при спортивній грижі у футболіста.

TAPP: 1) різниця розмірів пахових каналів від 1,5 до 4 мм; 2) підвищення МР-сигналу від пахового каналу визначається з обох сторін; 3) біль має двобічний характер за ВАШ від 7 до 10 балів.

Пошук ефективного хірургічного способу для лікування спортивної грижі, що відповідали ви- могам професійних спортсменів, розпочався ще у 80-ті роки. На початку Гілмор популяризував концепцію хронічного болю в пахвинній ділянці у спортсменів, який виникає на фоні занять спортом і супроводжується послабленням задньої стінки (posterior wall deficiency (PWD)) пахвинної ді- 
лянки в результаті пошкодження поперечної фасції чи серпоподібного апоневрозу. 3 урахуванням цих патологічних змін пахвинної ділянки проводились хірургічні втручання з відновлення пошкоджень пахового серпа та зовнішнього косого м'яза живота, при цьому зазначено, що до 40 \% спортсменів мали пошкодження прямого м'яза живота чи м'язів-аддукторів стегна. У свою чергу, Meyer та інші з врахуванням клінічної симптоматики та МРТ ознак запропонував хірургічні методики, які передбачають відновлення сухожилкових з'єднань цієї ділянки шляхом прикріплення в місцях фіксації сухожилка довгого м'яза стегна. В 2003 р. Dr. Muschaweck and Dr. Berger запропонували відкриту шовну методику Minimal Repair technique [17], метою якої було стабілізувати задню стінку за допомогою ненатяжних швів через мінідоступ та позбавити від болю завдяки декомпресії генітальної гілки нерва genitofemoralis. У 2008 p. Lloyd та інші для спортсменів із болем у ділянці лонного симфізу в місці кріплення пахвинної зв'язки запровадив лапароскопічну хірургічну методику, в основі якої проводиться реліз пахвинної зв'язки від лонної кістки та укріплення пахвинної ділянки за допомогою сітчастого алотранплантату. Додатково рубцеву тканину або шви від попередньої операції видаляють, проводять реліз стоншення гребінцевої фасції і при визначенні стоншення виділяють пошкоджений латеральний край піхви прямого м'яза живота [10]. Мarcy вперше розглянув важливість внутрішнього пахового кільця та запропонував використовувати анулопластику для лікування спортивної грижі [15].

Переваги лапароскопічних хірургічних втручань від відкритих: швидке повернення до гри у футбол, мінімальний післяопераційний біль, низький ризик ранових ускладнень, можливість візуалізації обох пахових ділянок та зручність виконання герніопластики з обох сторін, косметичний ефект.

Однією з переваг лапароскопічних методик хірургічного втручання $€$ можливість виявлення “слабкості задньої стінки” пахвинного каналу та розширення внутрішнього пахового кільця 3 протилежної сторони. Так у 6 хворих розширення внутрішнього пахового кільця пахового каналу з протилежної сторони візуалізували інтраопераційно. Для ушивання внутрішніх пахових кілець застосовували поліпропіленову нитку 2-0 та 3 прооперованих пацієнтів у післяопераційному періоді скаржилися на дискомфорт у ділянці післяопераційного вузла, який був розміщений субдермально в пахвинній ділянці. Враховуючи натяг швів у ділянці внутрішнього пахового кільця у дорослих та відсутність різниці в результатах у першій та другій підгрупах футболістів, ушивання внутрішніх пахових кілець надалі не проводилось. У одного пацієнта в ході операції при субдермальному ушиванні внутрішнього пахового кільця було пошкоджено гілку а. epigastrica, при цьому гемостаз досягнуто за допомогою ультразвукових ножиць.

Потребує проведення хірургічного втручання з обох сторін при наявності спортивної грижі з однієї сторони та при своєчасному прогнозуванні її 3 протилежної сторони [14].

Також виявлено, що спосіб фіксації сітчастого трансплантату впливає на показник болю в післяопераційному періоді. У пацієнтів, яким було проведено хірургічне лікування спортивної грижі за методикою ТАРР зі встановленням самофіксуючого сітчастого трансплантату, на 2-гу добу спостерігали лише дискомфорт в ділянці п/о рани від 1 до 3 балів, тоді як у пацієнтів після лапароскопічної герніопластики за методикою IPOM зі встановленням сітчастого трансплантату, який фіксували за допомогою герніостеплера на 2-гу п/о добу, спостерігали від 4 до 6 балів за ВАШ. Пацієнти, яким проводилось субдермальне ушивання внутрішніх пахових кілець, скаржилися на дискомфорт у паховій ділянці від 3 до 6 балів.

Важливим фактором при виборі методики хірургічного втручання для спортсмена $€$ його швидке відновлення після хірургічного втручання та час повернення до тренувань та гри у футбол. Терміни повернення до тренувань у пацієнтів після хірургічного втручання методикою ТАРР зі встановленням самофіксуючого сітчастого трансплантату - 3 тижні, після лапароскопічної методики IPOM - 3,5 тижня, після IPOМ з ушиванням внутрішнього пахового кільця - 4 тижні.

Найнижчий ризик виникнення больового синдрому при спортивній грижі після пластики задньої стінки пахвинного каналу за методикою ТАРР. При пластиці спортивної грижі за методикою IPOM, яка виконується трансабдомінально передочеревинно без виділення очеревини, $є$ імовірність недостатньої ревізії проекції медіальної та латеральної пахових ямок, зокрема рубцевих зрощень із залученням нервів, наявність додаткових утворень в ділянці сім'яного канатика, що в подальшому може бути причиною невирішених причин пахового болю. Тоді як при застосуванні методики ТАРР інтраопераційно виконується розсічення рубцевих зрощень, що дає можливість провести достатню інструментальну ревізію пахвинної ділянки.

На рисунку 5 представлено знімки МРТ пахвинної ділянки до та після хірургічного лікування. Пацієнт Н., 1998 р. н. повернувся до гри у футбол на попередній рівень кваліфікації через 3 тижні. На МРТ пахвинної ділянки при динамічному спостереженні через 1 рік ознаки регресу ARSсиндрому ліворуч. 


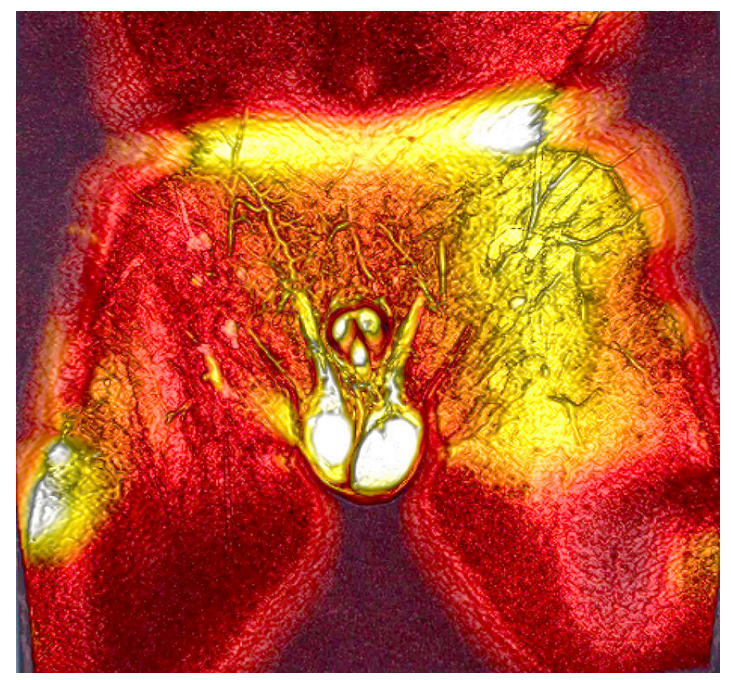

a

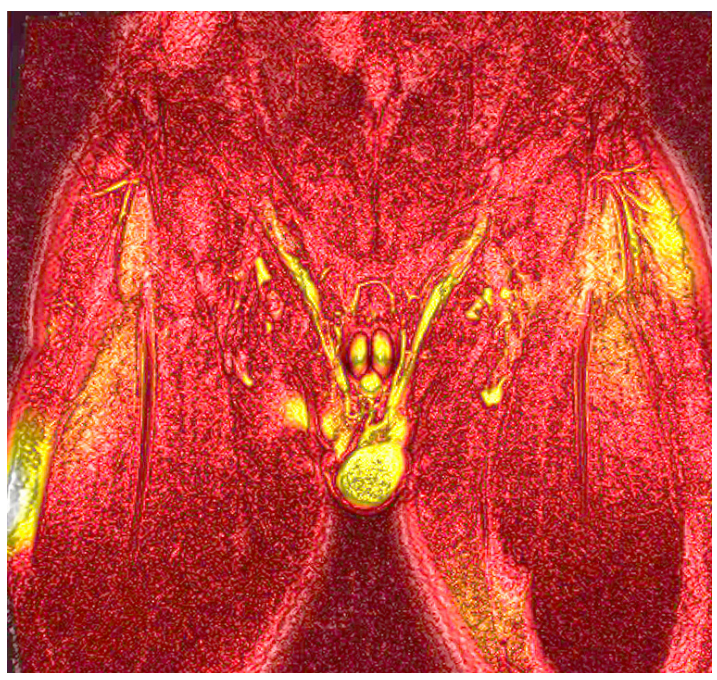

б

Рис. 5. МРТ пахвинної ділянки до та після хірургічного лікування: а - пацієнт Н., 1998 р.н. МРТ пахвинної ділянки до операції. MPT-ознаки ARS-синдрому ліворуч та спортивної грижі представлені у вигляді підвищення MP-сигналу в проекції привідних м’язів лівого стегна та пахвинних каналів праворуч та ліворуч; б - пацієнт Н., 1998 р.н. МРТ пахвинної ділянки після операції через 1 рік, ознаки регресу ARS-синдрому ліворуч.

Перевагами цієї методики хірургічного лікування $є$ надійне укріплення задньої стінки пахвинного каналу у спортсменів, а встановлення сітчастого алотрансплантату з обох сторін забезпечує рівномірний розподіл інтраабдомінального тиску, а також перерозподіл навантаження в проекції передньої черевної стінки під час футбольної гри, що дає можливість у короткий термін повернутись до спортивних змагань без рецидиву больового синдрому в пахвинній ділянці.

Висновки 1. Критерієм ефективності хірургічного лікування спортивної грижі визначено відсутність болю у футболіста під час удару по м’ячу.

\section{СПИСОК ЛІТЕРАТУРИ}

1. Meyers W. C. Core muscle injury (a better name than "athletic pubalgia” or "sports hernia”) / W. C. Meyers, B. K. Havens, G. J. Horner // Current Orthopedics Practice. - 2014. - Vol. 25. - C. 321.

2. Brannigan A. E. Gilmor's groin repair in athletes / A. E. Brannigan, M. Kerin, G. P. McEntee // J. Orthopaedic \& Sports Physical Therapy. - 2000. - Vol. 30, No. 6. - P. 329-332.

3. Caudill P. Sports hernias: a systematic literature review/ P. Caudill, J. Nyland, C. Smith// Br. J. Sports Med. - 2008. Vol. 42. - P. 954-964.

4. Новий спосіб хірургічного лікування кили Гілмора / І. Д. Герич, І. В. Стояновський, Г. І. Герич, О. М. Чемерис //Український журнал хірургії. - 2011. - Том 2. - № 11. C. 104-108.

5. Santilli O. L. Sports hernias: Experience in a sports medicine center / O. L. Santilli, N. Nardelli, H. A. Santilli // Hernia. - 2016. - Vol. 20, No. 1. - P. 77-84.
2. Лапароскопічну техніку необхідно розглядати як метод вибору хірургічного лікування спортивної грижі у спортсменів.

3. Найкоротший термін повернення спортсмена до тренувань після хірургічного лікування спортивної грижі виявлено при лапароскопічній пластиці задньої стінки пахового каналу за методикою ТАРР зі встановленням самофіксуючої сітки і становить 3 тижні.

4. Необхідним $є$ проведення хірургічного лікування зі встановленням сітчастого алотрансплантату з обох сторін при наявності спортивної грижі з однієї сторони та при своєчасному прогнозуванні іiї з протилежної.
6. Doha agreement meeting on terminology and definitions in groin pain in athletes / P. Brukner, E. Delahunt, J. Ekstrand [et al.] // British Journal of Sports Medicine. - 2015. - Vol. 49, No. 12. - P. 768-774.

7. High incidence of athletic pubalgia symptoms in professional athletes with symptomatic femoroacetabular impingement / S. Hammoud, A. Bedi, E. Magennis [et al.] // Arthroscopy. -2012. - Vol. 28. - No. 10. - P. 1388-1395.

8. Swan K. G. The athletic hernia systematic review / K. G. Swan, M. A. Wolcott // Clin. Orthop. Relat. Res. - 2007. Vol. 455. - P. 78-87.

9. Experience with "sports hernia" spanning two decades / W. C. Meyers, A. McKechnie, M. J. Philippon [et al.] // Ann. Surg. - 2008. - Vol. 248. - P. 656-665.

10. Laparoscopic inguinal ligament tenotomy and mesh reinforcement of the anterior abdominal wall: a new approach for the management of chronic groin pain / D. M. Lloyd, C. D Sutton, 


\section{ОРИГІНАЛЬНІ ДОСЛІДЖЕННЯ}

A. Altafa [et al.] // Surg. Laparosc. Endosc. Percutan. Tech. 2008. - Vol. 18. - P. 363-368.

11. Иоффе А. Ю. Лапароскопическая интраабдоминальная герниопластика как операция выбора при лечении паховой грыжи / А. Ю. Иоффе, А. В. Васильев // Клінічна хірургія. 2012. - № 1. - С. 26-29.

12. The Copenhagen Hip and Groin Outcome Score (HAGOS): Development and validation according to the COSMIN checklist / K. Thorborg, P. Hölmich, R. Christensen [et al.] // British Journal of Sports Medicine. - 2011. - Vol. 45, P. 478-491.

13. http://www.eurahs.eu/EuraHS-Quality-of-Life-Score.

14. Оцінка причин больового синдрому в пахвинній ділянці та прогнозування спортивної грижі у футболістів за допомо-

\section{REFERENCES}

1. Meyers, W.C., Havens, B.K., \& Horner, G.J. (2014). Core muscle injury (a better name than "athletic pubalgia" or "sports hernia’'). Current Orthopedics Practice, 25, 321.

2. Brannigan, A.E., Kerin, M., \& McEntee, G.P. (2000). Gilmor's groin repair in athletes. J. Orthopaedic \& Sports Physical Therapy, 30 (6), 329-332.

3. Caudill, P., Nyland, J., \& Smith, C. (2008) Sports hernias: a systematic literature review. Br. J. Sports Med., 42, 954-964.

4. Gerich, I.D., Stojanovskiy, I.V., Gerich, G.I., \& Chemerys, O.M. (2011). Novyi sposib khirurhichnoho likuvannia kyly Gilmora [A new method of surgical treatment of Gilmore hernia]. Ukrainskyi zhurnal khirurhii - Ukrainian Journal of Surgery, 2 (11), 104-108 [in Ukrainian].

5. Santilli, O.L., Nardelli, N., \& Santilli, H.A. (2016). Sports hernias: Experience in a sports medicine Center Hernia, 20 (1), 77-84.

6. Weir, A., Brukner, P., Delahunt, E., Ekstrand, J., Griffin, D., \& Khan, K. et al. (2015). Doha agreement meeting on terminology and definitions in groin pain in athletes. British Journal of Sports Medicine, 49 (12), 768-774.

7. Hammoud, S., Bedi, A, Magennis, E, Meyers, W.C., \& Kelly, B.T. (2012). High incidence of athletic pubalgia symptoms in professional athletes with symptomatic femoroacetabular impingement. Arthroscopy, 28 (10),1388-1395.

8. Swan, K.G, Wolcott, M. (2007). The athletic hernia. A systematic review. Clin. Orthop. Relat. Res., 455, 78-87.

9. Meyers, W.C, McKechnie, A., \& Philippon, M.J. (2008) Experience with "sports hernia" spanning two decades. Ann. Surg., 248, 656-665.

10. Lloyd, D.M, Sutton, C.D., \& Altafa, A. (2008). Laparoscopic inguinal ligament tenotomy and mesh reinforcement of the anteri- гою магнітно-резонансної томографії та ультразвукового дослідження / О. П. Стеценко, А. В. Омельченко, Ю. А. Діброва [та ін.] // Хірургія Донбасу. - 2019. - Том 8, № 3. - С. 24-33. 15. Valenti G. The Marcy repair modified using cremaster muscle sparing. A new and effective method for performing prosthetic hernioplasty / G. Valenti, E. Baldassarre, A. Conforti // Surg. Today. - 2005. - Vol. 35, No. 8. - P. 645-648.

16. R Core Team. Vienna: R Foundation for Statistical Computing. -2016

17. Muschaweck U. Sportsmen's groin - diagnostic approach and treatment with the minimal repair technique: a single center uncontrolled clinical review/U. Muschaweck, L. Berger // Sports Health. - 2010. - No. 2. - P. 216-221.

or abdominal wall: a new approach for the management of chronic groin pain. Surg. Laparosc. Endosc. Percutan. Tech., 18, 363368.

11. Ioffe, O.Y., \& Vasiljev, A.V. (2012). Laparoskopichna intraabdominalna hernioaloplastyka yak operatiia vyboru pry likuvanni pakhovoi hryzhi [Laparoscopic intra-abdominal hernioplasty as the operation of choice in the treatment of inguinal hernia]. Klinichna khirurhiia - Clinical Surgery, 1, 26-29 [in Ukrainian]. 12. Thorborg, K., Hölmich, P., \& Christensen, R. (2011) The Copenhagen Hip and Groin Outcome Score (HAGOS): development and validation according to the COSMIN checklist. British Journal of Sports Medicine, 45, 478-491.

13. http://www.eurahs.eu/EuraHS-Quality-of-Life-Score.

14. Ioffe, O.Y., Stetsenko, O.P., Omelchenko, A.V., Dibrova, Y.A., Tsiura, Y.P., Tarasiuk, T.V., \& Vasilyev, A.V. (2019) Otsinka prychyn bolovoho syndromu v pakhvynnii diliantsi ta prohnozuvannia sportyvnoi hryzhi u futbolistiv za dopomohoiu mahnitno-rezonansnoi tomohrafii ta ultrazvukovoho doslidzhenniia. [Groin pain assesment and sports hernia prognosis with MRI and ultrasound criteria in football players]. Khirurhiia Donbassu - Surgery of Donbass, 8 (3), 24-33 [in Ukrainian].

15. Valenti, G., Baldassarre, E., \& Conforti, A. (2005). The Marcy repair modified using cremaster muscle sparing. A new and effective method for performing prosthetic hernioplasty. Surg. Today, 35 (8), 645-648.

16. $R$ Core Team. Vienna: R Foundation for Statistical Computing, 2016

17. Muschaweck, U., \& Berger, L. (2010) Sportsmen's groin diagnostic approach and treatment with the minimal repair technique: a single center uncontrolled clinical review. Sports Health, 2, 216-221. 


\section{O. Y. IOFFE, A. V. OMELCHENKO, O. P. STETSENKO, T. V. TARASIUK}

O. Bohomolets National Medical University

\section{THE FEATURES OF SPORTS HERNIA SURGERY IN FOOTBALL PLAYERS}

The aim of the work: to determine the optimal way to choose the method of surgical treatment for sports hernia in football players. Materials and Methods. An analysis of the results of surgical treatment of 36 football players of professional and amateur clubs aged 18 to 34 years with a diagnosis of sports hernia, who were in the Surgical Department of Kyiv City Clinical Hospital No. 3 in 2014-2019.

Patients were divided into two groups of studies depending on the method of surgery. In group 1 there were two subgroups, subgroup 1 of patients included 10 football players, who underwent laparoscopic intraperitoneal hernia alloplasty according to the IPOM method. Subgroup 2 included 8 football players, who underwent laparoscopic intraperitoneal hernia alloplasty according to the IPOM method with subdermal suturing of the internal inguinal rings. Group 2 included 18 football players, who underwent laparoscopic transabdominal preperitoneal hernia alloplasty (TAPP). The Copenhagen Hip and Groin Outcome Score (HAGOS) and the Eura HS Quality of Life score (Eura HS-QoL in modification) were used to assess the quality of life indicators.

Results and Discussion. In the analysis of indicators according to the HAGOS scale, the quality of life before surgery did not differ in both groups of the study, while after surgery significantly increased in group 2 from 47 to 96 points and group 1 - from 45 to 80 points $(\mathrm{p}<0.05)$. Also in group 2 there was a significant reduction in groin pain after laparoscopic hernioaloplasty (TAPP) from 8 points to 2 points on the VAS in scale and after the application of IPOM in group $1-$ from 7.5 to 3 points $(\mathrm{p}<0.05)$. The shortest period for return of the athlete to play is 3 weeks after surgical treatment of sports hernia by TAPP laparoscopic repair of the posterior wall of the inguinal canal with a self-fixing mesh.

The study conducted a comparative analysis of the results of laparoscopic surgical methods and determined the optimal way to choose the method of surgical treatment for sports hernia in football players.

Key words: sports hernia; surgical treatment; football players; TAPP; IPOM; groin pain.

А. Ю. ИОФФЕ, А. В. ОМЕЛЬЧЕНКО, А. П. СТЕЦЕНКО, Т. В. ТАРАСЮК

Национальный медицинский университет имени А. А. Богомольца

\section{ОСОБЕННОСТИ ХИРУРГИЧЕСКОГО ЛЕЧЕНИЯ СПОРТИВНОЙ ГРЫЖИ У ФУТБОЛИСТОВ}

Цель работы: определить оптимальную тактику выбора хирургического лечения спортивной грыжи у футболистов.

Материалы и методы. Проведен анализ результатов хирургического лечения 36 футболистов профессиональных и аматорских клубов в возрасте от 18 до 34 лет с диагнозом спортивная грыжа, которые находились в хирургическом отделении КГКБ № 3 в 2014-2019 гг.

Больные разделены на две группы исследования в зависимости от методики хирургического вмешательства. В первой группе выделены две подгруппы, в первую подгруппу больных вошли 10 футболистов, которым выполнялась лапароскопическая интраперитонеальная герниоаллопластика по методике IPOМ. Во вторую подгруппу вошли 8 футболистов, которым выполнялась лапароскопическая интраперитонеальная герниоаллопластика по методике IРОМ с субдермальным ушиванием внутренних паховых колец. Во вторую группу вошли 18 футболистов, которым выполнялась лапароскопическая трансабдоминальная преперитонеальна герниоаллопластика по методике ТАРP. Для оценки показателей качества жизни применяли опросник Тһе Copenhagen Hip and Groin Outcome Score (HAGOS) и Eura HS Quality of Life score (Eura HS-QoL в модификации).

Результаты исследований и их обсуждение. При анализе показателей по шкале HAGOS качество жизни до операции не отличалось в обеих группах исследования, тогда как после проведения хирургического лечения качество жизни значительно повысилось во второй группе с 47 до 96 баллов и в первой группе с 45 до 80 баллов (р<0,05). Также во второй группе отмечалось достоверное уменьшение болевого синдрома в паховой области после лапароскопической герниоаллопластики по методике ТАРР с 8 баллов до 2 баллов по шкале ВАШ и после применения методики IPOМ в первой группе - с 7,5 до 3 баллов (р<0,05). Кратчайший срок возвращения спортсмена к тренировкам составляет 3 недели после хирургического лечения спортивной грыжи при лапароскопической пластике задней стенки пахового канала по методике ТАРР с установкой самофиксирующей сетки. В исследовании сделан сравнительный анализ результатов лапароскопических хирургических вмешательств и определена оптимальная тактика выбора хирургического лечения спортивной грыжи у футболистов.

Ключевые слова: спортивная грыжа; хирургическое лечение; футболисты; ТАРP; IPOМ; боль в паховой области. 